\title{
The Effect of Innovative Capabilities and Entrepreneurial Attitude on Performance of Small and Medium Scale Enterprises in Ghana
}

\author{
Job Addae, \\ School of Business, Christian Service University College \\ Post Office Box 3110, Kumasi, Ghana \\ Email: baddae88@gmail.com \\ Jerry Jay Kraa \\ School of Business, Christian Service University College \\ Post Office Box 3110, Kumasi, Ghana \\ Email: kraaj2@yahoo.com \\ Vida Oppong Boachie \\ School of Business, Christian Service University College \\ Post Office Box 3110, Kumasi, Ghana \\ Email: boachievida23@gmail.com \\ Gladys Agyeiwaa Bediakoh \\ School of Business, Christian Service University College \\ Post Office Box 3110, Kumasi, Ghana \\ Email: bediakohgladys@gmail.com
}

\begin{abstract}
Considering the competitive nature of SMEs environments, developing innovative capabilities is vital for survival. The study assessed the effect of innovative capabilities and entrepreneurial attitude on the performance of SMEs in Ashanti Region of the republic Ghana. The population comprised of SMEs (registered and unregistered) owners with a sample size of 400 . A response rate of $98.75 \%$ was achieved. Purposive and convenience sampling techniques were adopted and questionnaires used in collecting data. Multiple linear regression was used in establishing the relationship among the variables with the use of Statistical Package for Social Scientist software. The study found innovative capabilities variables of product, process, marketing and organisational innovativeness having positive and significant effect on performance of SMEs. Entrepreneurial attitude also positively and significantly impacts on SMEs performance.
\end{abstract}

Keywords: Innovative Capabilities, Entrepreneurial Attitude, Small and Medium Scale Enterprise, Performance. DOI: $10.7176 / \mathrm{EJBM} / 12-21-19$

Publication date:July $31^{\text {st }} 2020$

\section{Introduction}

Because of the increased presence of small and medium-sized enterprises (SMEs) in the financial settings, SMEs are an important component of economic growth (Bruque \& Moyano, 2007; Zeng et al., 2010) and they contribute to innovative activities within the economic space (Akman \& Cengiz, 2008). Globally in today's technological driven economies, SMEs constitute greatly to the vital forces that drives economic progress (Mitchell \& Reid, 2000). SMEs are seen as a genuine vehicle for achieving domestic macroeconomic goal of job creation and improving apprenticeship training in business management (Osotimehin et al, 2012). Although there are varying definition of SMEs (Quartey et al., 2017), numerous literatures seeking to define SMEs in Ghana have given different definitions, but the number of workers are usually used as a basis for many definitions (Kusi et al., 2015). The Ghana Statistical Service recognizes businesses with less than ten workers as small-scale enterprises and their colleagues with more than ten workers as medium- and large-sized businesses (Cofie, 2012). Companies in Ghana whose total assets value less than One Million United States Dollars are considered as a small or medium scale enterprise. (Venture capital trust fund Act, 2004, Act 680). 
In Ghana, the SME segment contributes over 70\% of Ghana's Gross Domestic Product (GDP) (Villars 2004), and represent about $92 \%$ of organizations. SME's don't just add to the development of national GDP, SMEs employ the highest number of individuals in developing nations (Loza, 2017).

Notwithstanding, SME's are being seen as a hotspot for occupation creation and business, (Pang et al., 2014). Strategy inventors, market analysts, and business specialists concede that SMEs are the drivers of financial innovation as they have added to over half of the Gross Domestic Product (GDP) and gave over $60 \%$ of the allout work in growth, (Subrahmanya et.al 2010). Both the developed and developing nations are firmly occupied with and keep on looking for down to business methods for improving SMEs (World Bank in 2010). SMEs that are able to build innovative capabilities can aggressively and consistently develop a winning strategy that gives them competitive advantages (Agyapong et al. (2016).

In business, innovation is an organisation's process for acquiring new thoughts, work processes, approaches, products or enhancing existing administrations (Caetano \& Amaral, 2011). Pinto et. al. (2017) sees innovation as bringing new products or changes in the existing ones, using new methods to decrease costs, developing a firm's system, recognizing the role of market and increasing productivity. Studies demonstrate that organizations that can manufacture reasonable upper hands over significant lots are those that have actualized a progression of advancements (Hamel, 2006). Innovation is seen as a key factor of SMEs' development and improvement (Terziovcki, 2010). Kuswantoro et.al (2012), states that innovation is a key driver for organizations to pursue intensively and improve. Innovation limit portrays an organisation's as ceaseless improvement of its capacities and assets to explore and use the chances of new product improvement to meet market desires (Forsman, 2011).

A firm performance is identified with the capacity of the firm to identify opportunities and innovation so as to accomplish its general objectives. Keizer et al (2015) underscored that a company's innovation accomplishment relies upon how open a companies is to their outside circumstance. This will rely upon the knowledge base of the business entrepreneurs just as their traits that might want to impact firm innovative capacity. It tends to be contended that business people have been accounted for in character and mental research to display interesting qualities that distinguish them from others (Ndubisi and Kahraman 2005). Self-confidence (Zimmerer and Scarborough 2005), need for achievement (George and Zhou 2001), Independence (Shane et al. 2003), and Proactivity (Seibert et al. 2001) have been recognized by scientists as proof of experimental investigation supporting the impact on innovation. Today enterprise is an asset to quicken business innovation and achievement. Business people are assuming a significant job in making worth and occupations in created and creating nations (Peng, 2011). Business people's tendency to manage their organizations relies upon the utilization of their solid explicit characteristics (Dvir, et al., 2010). Beugelsdijk and Noorderhaven (2004) found a solid constructive connection between the entrepreneur's attributes of the people and a rate of provincial financial development. It is undisputed that the character of the entrepreneurs of small scale enterprises altogether impacts their performance.

Notwithstanding the contribution of SMEs to Ghana's economic development through the creation of employment and reduction of poverty (Abor \& Quartey 2010), SMEs sustainability in Ghana continues to decline because of the varying risks they are exposed to. Businesses are highly challenged with some of them folding up at a relatively higher rate due to numerous economic factors including competition (Bowen et al., 2009) and SMEs in the Kumasi Metropolis are not an exception. To ensure business survival, entrepreneurs continue to introduce innovative strategies that are used as a competitive tool to fight competition. Some SMEs succeed in getting through with their innovative strategies whilst others do not. In Ghana, most SMEs are operated and managed by their owners. This leaves one to think about the relationship between the entrepreneur's attitude towards the innovative activities and the business's performance in general. Notwithstanding the numerous research studies about performance of businesses globally, few studies have investigated innovation capacity as a factor in SMEs' innovation and performance (Forman, 2011).

Despite a clear correlation between innovation and performance, the factors that can enhance innovation remain unclear and need further investigation (Forsmann, 2011). In the SMEs sector, innovation-increasing factors remain ambiguous (De jong \& Marsilli, 2006) and previous literature has fails to provide a sufficient empirical exploration of the concept and its foundations (Forsman, 2011; Mansury \& Love, 2008). The aim of this research is to fill the research gap concerning the assessment of the innovation capacity of SMEs in the Kumasi (Second largest City in Ghana) Metropolis of the republic of Ghana by examining innovative capabilities of SMEs and measuring their influence on SME innovation and performance. 


\section{Literature review}

\subsection{Innovative Capabilities}

In today's competitive business world, one of the basic elements for survival is innovativeness and the ability to adopt to the fast changing demand of customers. Innovation has been the engine on which company's competitive strategies run. Kuswantoro et.al (2012), states that innovation is a key driver for companies to pursue competitiveness and improve the performance of SMEs. This goes a long way to confirm that innovation is very instrumental in the success of every SMEs. The ability to innovate simply referred to innovative capabilities and is increasingly viewed as the most important in developing and sustaining competitive advantage (Tiddet.la 2001). For SMEs to wind up inventive, SMEs need to create imaginative abilities. The expression "capacities" stresses the key job of vital administration in fittingly adjusting, incorporating, and reconfiguring authoritative abilities, assets, and practical capabilities to coordinate the prerequisites of an evolving situation. Innovation ability is made out of the primary procedures inside the firm (Lawson and Samson, 2001). That is, it can't be isolated from different practices. As per Neely et al. (2001), an organisation's innovation ability can be thought of as the possibility to create imaginative yields. Lawson and Samson (2001) be that as it may, portrayed innovation capacity as "the capacity to ceaselessly change learning and thoughts into new products, process, and frameworks to support the firm and its partners.

An organisation's aggressiveness will be significantly increasingly subject to its capacity to create innovations later on (Alasoini et al. 2007), in this manner, it tends to be expected that an organisation's presentation is increasingly more reliant on its innovation ability (Alasoini et al., 2007). Guijaro, (2009) concluded, innovative activities are a necessity considering the scarce resources of SMEs. Innovation can only occur if a firm has the capability to innovate (Laforet, 2011). According to Laforet, the capacity to innovate should be seen as the engine on which innovation runs. Assets speak to a lot of accessible components claimed by the organizations, though capacities speak to an organisation's capacity to convey those assets as indicated by their process, schedules and all the company's exercises installed in that process. Hierarchical assets ought to be plainly recognized from their abilities (Forsman, 2011). SMEs that commit themselves to the innovation of their innovation capacity have better odds of prevailing later on. Agyei-Mensah (2016) checked on that, organisations that can create inventive abilities increased in value by their clients, accomplish upper hand. Innovation capacity is defined as a firm's ability to continuously improve on its capabilities and resources to discover and exploit the opportunities of new product development to meet market expectations (Boly et al., 2014). Oslo (2011) built up a model that utilizations four distinct kinds of innovation (product innovation, process advancement, authoritative or administrative advancement, and promoting innovation) to quantify the inventive abilities of a firm. This examination embraced OSLO Manual's measurement and utilized it as a build of estimation to gauge the innovation ability of Small and Medium-Scale Enterprises (SMEs) in Ghana.

A company is said to be innovating its products when the company introduce a new product onto the market or modify and existing product in the market. This leads to enhancements of product features, usage or packaging (OECD (2012). New products are products that vary fundamentally in their expected uses from products previously created by the firm. New uses for products, is the innovation of another usage for a product with just minor changes to its specialized features. A research work by Ibidunni et al, (2014) established a significant and positive relationship between product innovation and a boost in sales volume, while Thulin et. al. (2016) conclude that product innovation increases the growth of small scale enterprises more than process innovativeness. However, scholars through research has concluded that most SMEs are more likely to adopt the usage of process-oriented innovativeness than product-oriented innovativeness due to financial constraint (Rahman, Yaacob, \& Radzi, 2016). Siantova et. al. (2015) defines process innovation as a process of recognizing customer needs and innovation opportunities, generating innovative ideas and their embellishment, working with information and knowledge regarding innovation, realization of innovation activities and ensuring successful extension of innovation among customers of a firm. Process innovation also involves the process of carrying out sequential activities or task of transforming creative ideas to products and/or a services (Siantova et. al. 2015). Companies that successfully adopt process innovations usually gains productivity growth by reducing cost of labour and capital. Lack of innovative expertise, failure to secure the flow of information in a firm, insufficient training and motivation of employees are seen as the causes of process failure among organisations. (Lendel, Hittmara, \& Siantova, 2015). Intellectual property rights are used as a protection for process-oriented innovativeness (Claudio \& Andreas, 2014).

Correspondence inside the firm, between the firm and its clients and providers is a basic innovation to the achievements in product innovation. Also, the accomplishment of product/administration innovations can be accomplished through the improvement of process (Oke, 2007). Furthermore, advertising and product innovation 
are decidedly related. Both have impact on one another (OECD, 2005). This prompts upper hand increment. Firm money related execution can be improved through advancement, for example, the capacity to reaction rapidly to market powers, create and dispatch new products with a lower lead times (OECD, 2005). In Ghana, SMEs that embrace product imaginative practices recorded a noteworthy innovation as far as the yearly turnover (Forkuoh et. al., 2016). Ansah-Appienti et. al., (2016) set that Ghanaian SMEs in the urban communities and with taught business people receive to product innovation to the detriment of those in the country regions. Various systems, including the product life cycle and innovation shared framework, hypothesize the requirement for product advancements that create future productivity and forestall the out of date quality of organisation's product offering. Creation strategies or conveyance techniques, or both (OECD (2011) can recognize process innovations. Creation strategies are strategies that include the methods, hardware, and programming used to deliver products or administrations. Conveyance strategies anyway are worry with the coordination of the firm and envelop gear, programming, and systems to source inputs, dispense supplies inside the firm or convey last products. Fagerberg et al. (2004) stressed that cost-slicing nature because of the process innovation will positively affect the innovation of salary and business.

Administrative innovation is the progressions in authoritative structure or regulatory process. As indicated by Greenan, (2003), authoritative innovation alludes to an adjustment in the manner choices are taken: changes in the designation of obligations, in the manner in which the data is organized, and in correspondence structures inside the organisation. This incorporates new or noteworthy enhancements to the board frameworks or working environment of the organisation (Bloch and Bugge 2013). At the end of the day, it is a path in the organisation to confront the structure and process that are essentially not quite the same as the present practices in the organisation and have a financial effect (Tyni et. al., 2009). It tends to be inferred that a regulatory innovation makes time and monetary advantages by encouraging the collaboration of business capacities. Mergers and acquisitions cause an authoritative innovation (Günay, 2007). Polder et al. (2010) accept that a regulatory innovation is characterized as presenting new strategic approaches, sorting out strategies, basic leadership frameworks and new ways to deal with oversee outside relations.

\subsection{SMEs Performance}

Performance, as an idea, is a subject open to wide inconstancy as it is a to some degree uncertain word when it works as a placeholder in research (Folan et. al 2007). The absence of concession to a definition makes disarray and plainly confines the potential for generalisability and equivalence of research around there (Franco-Santos, et.al 2007). To precisely survey how well a business is performing, one needs to build up some quantifiable measures by recognizing those parts of the business forms that need improvement and those that are functioning admirably (According Molly 2013). This would then be able to be utilized to assess the organization's efficiency over a set period. The U.K based firm, Kellerton Consulting (2013) has seen that exhibition the executives ought to be at guaranteeing that however much data and basic leadership as could reasonably be expected is outfitted towards improving execution in accordance with the organisation's objectives and technique. Calantone et al. (2002) set that inventiveness is the most significant determinant of an organisation's presentation. Business execution is principally determined by a significant factor that is innovation (Desh-pande and Farley, 2004) and is critical for aggressiveness (Bastič, 2004). Empirical ponder by Langerak et al., (2004) affirms a positive connection between new-product execution and business execution; Ledwith and O'Dwyer, 2008). Client steadfastness, piece of the overall industry, and deals volume is emphatically affected by the adequacy by new-product innovation process and the capacity to effectively dispatch new products. Administrative, product and procedure innovation are identified with business execution in positive manner. Business execution term is utilized as a general execution develop to keep both market and budgetary parts of introduction, (Rust et al., 2004). Clark (1999) offered extended estimations of advertising execution, which incorporate the money related perspective that is, productivity, saleability, income, and non-budgetary or showcasing viewpoint that is, consumer loyalty, client reliability and brand value.

Financial performances refer to the ability of a company to excel in financial aspects of the business. Financial performance according to scholars is measured by organization's sales performances, (Li.L, 2000). Kitapci al et, posit that sales value, and general profit of an organisation can be used as a perimeter for financial performance (Kitapci, Aydin, \& Celik, 2011). An organisation's sales are largely affected by its ability for innovate their products effectively (Wei \& Wang, 2005). Marketing performance refers to market growth, cost reduction, revenues, customer satisfaction, customer loyalty, brand equity and market share of a firm. Prior study results have shown that innovation capability relates positively to market performance of an organisation. Market innovation should be seen and considered the most significant factor without which market performance can be achieved (AMA 2005). Financial performance is largely determined by the sales performance of the firm. 


\subsection{Entrepreneurial Attitude}

Entrepreneurship pursue invention and exploitation of profitable opportunities (Shane and Venkataraman, 2000). An entrepreneur creates or develops things that nobody has considered it before. Per Zimmerer and Scarborough (2005) entrepreneur is one who creates a brand new business within the face of risk and uncertainty for the aim of achieving profit and growth by identifying distinctive important opportunities and the required resources to capitalise on them.

Generally, SMEs in Ghana are run on the ideals and values of the entrepreneur. Additionally, the success of SMEs' choices heavily depends on the temperamental traits of entrepreneurs (Antoncic et al.2008). Thus, their success or failure depends on the resources obtainable to the entrepreneur. These resources, Nunoo and Andoh (2012) argue, includes financial literacy level of the SME-owner and cultural values. Others have cited knowledge, habits, social, and personality attributes as factors influencing entrepreneurial intentions (Unger, Rauch, Frese, \& Rosenbusch, 2011). Studies on entrepreneurship from identity characteristics are concentrated on few ranges. Hisrich (2000) study of the business person from identity perspectives concentrated on three areas: need for achievement, risk-taking behaviour, and internal locus of control or self-confidence. Johnson, Newby and Watson (2005) contended based on later surveys of the entrepreneur personality traits that; need for achievement, risktaking behaviour, and self-confidence might not be adequately comprehensive in looking at the part played by identity in deciding entrepreneurial inspiration.

Opportunity-recognition as an entrepreneurial action contains not as it were new product innovation but moreover the identification of new markets and opportunities, such as customers' market needs. Again, innovation includes the method of creation of new ideas and recognizing new opportunities. Shane and Venkataraman (2000) sees entrepreneurial opportunity recognition as a process whereby people identify, recognize, and discover potential opportunities create and develop new business, ventures, markets, and technology. As of late, analysts have emphasized the significance of business enterprise not as it were to energize the improvement of unused trade but too the acknowledgment and interest of modern entrepreneurial openings (De Carolis and Saparito, 2006; Fillis, 2006). Entrepreneurial opportunity acknowledgment contributed altogether to individual-level development execution (Ellinger, Wang \& Wu, 2013). Self-confidence is concerned with how an individual's feeling about his capacity. An effective business entrepreneur believes in his capacities and not frightened to explore un-chartered territories, take risk, and take troublesome decisions. Self-confidence, be that as it may, is not an individual trait that either one has or do not, but an attitude that can be learnt through training.

Innovativeness displays the tendency of businesses to promote new ideas, new experiments, and creative tactics that can also end result in new products, offerings or technological processes. Entrepreneurs' innovativeness and personalities play a key function in the adoption of innovations in SMEs (Marcati, Guido \& Peludo, 2008). Innovativeness as the potential to participate in innovation methods is a competence carefully linked to participation strategies in a dynamic, ever-changing society that wishes mature citizens who structure the present and the future in accordance with their ideas, interests and social responsibility (Weis, Scharf \& Gryl, 2017). According to Moreno and Casillas (2008), innovativeness of organizations can be described as the intention to encourage new creative ideas, experiments, and approaches that might also end result in new products, services, or technological processes. Innovativeness is associated with private characteristics of an entrepreneur, such as age, gender, professional experience, and monetary sources of a business enterprise (Boyer and Blazy 2014). Mahmood \& Hanafi (2013) state, that entrepreneurial orientation such as danger taking, pro-activeness, and innovativeness is substantially related to the employer performance. Generally, according to the 2011 International Conference on E-business report, entrepreneurs receive four types of dangers as follows: monetary risk, social and family risk, job risk and intellectual risk.

\subsection{Relationship among Innovative Capabilities, entrepreneurial attitude and Performance}

Innovation has continually been an essential aspect in ensuring the long-term survival of organizations. Researchers have linked innovation with economic and competitive outcomes (Carlsson et al., 2002). The larger an organization's capability to efficaciously and constantly boost innovation abilities the larger the advantage the company will acquire competitive advantages. The improvement of innovation capability as key organisational sources can be really useful to a company (Guan \& Ma, 2003). Moreover, Yam et al. (2004) concluded that innovation functionality is positively associated the introduction of new product and sales revenue. Current generation of models studied have shown an impact on of innovative capabilities on company performance has shifted focus to the complex innovation system and channels via which the innovation inputs are modified into higher overall performance (Loof, et al., 2002; Kemp, et al., 2003; Bessler, et al., 2008). Innovation capabilities impact of on businesses overall performance have decades been a count of huge interest to economists and policy makers. Though innovation is typically considered as a capacity of enhancing the competitiveness of companies 
and their overall performance on home and foreign markets, this relationship has not been supported unambiguously by means of empirical work. Innovative activities of companies impact their overall performance not always directly but thru the production of useful improvements and expanded productivity (Hashi \& Stojcic, 2010). Despite a clear correlation between innovation and performance, the elements that can enhance innovation stay unclear and need similarly investigation (Forsmann, 2011).

In the cutting-edge globalized-competitive enterprise world, corporations relentlessly undertake to progressive activities to reap and retain customers. Innovation continues to be a key strategic tool for businesses to differentiate itself from competitors. Innovation activities are then again strongly influenced by way of the chief of the SME (Julien and Carrier, 2002; Guijaro et al., 2009). SME competitiveness and innovation has been broadly used by using public institutions seeing that the Nineteen Eighties to foster competitiveness and world growth (Laperche, \& Uzunidis, 2010). In Ghana, the entrepreneurs themselves control most SMEs. The leaders of these SMEs are perceived to be the fundamental driver of innovation activities, and innovation things to do rely on its imaginative and prescient (O'Regan et al., 2005) its characteristics tend to structure the firm (Hyyarinen, 1990). According to preceding studies, two characteristics of SME entrepreneurs seem to have a widespread impact on SMEs' innovation activities. One characteristic consists of the non-public experiences (Romijn \& Albaladejo, 2002), know-how (Gronum, 2011), abilities and skills of the leader (Forsman, 2011).

The attitude of an entrepreneur is undoubtedly a predominant contributory element to the success of a commercial enterprise organisation. Nasuredin, Halipah, and Shamsudin (2016) concluded that entrepreneurial knowledge affected the commercial enterprise success in SMEs. Innovation however is viewed as a survival device in an aggressive business environment. Firms with excessive innovation capabilities are more profitable both in home and remote places markets than firms with lower innovation skills (Salomon, Shaver 2005). Rosenbusch et al. (2011) advised that innovation have a nice impact on SME performance and commercial enterprise success. The benefits of innovation are useful and far exceed the value of the resources to put in force it (Niera et al., 2009). In Ghana, innovation plays an essential function and have an effect on positively on overall performance of SMEs (Kraa 2016). Previous researches have confirmed that modern competencies and entrepreneurial attitudes are strongly related. Kazemi et al. (2016) determined a sizeable positive influence between innovation and entrepreneurial knowledge of a firm. Hashim (2018) concluded that entrepreneurial attitudes have a tremendous and significant impact on innovation and modern skills of a firm.

\section{Methodology}

This study adopts an explanatory research design in examining the effects of innovative capabilities and entrepreneurial attitude on performance. The population of the study comprises of all SMEs owners (both registered and unregistered) in the Kumasi (Second largest city in Ghana) Metropolis of the republic of Ghana with a sample size of 400 . The study used convenience and purposive sampling techniques to select respondents. Questionnaires were used for the primary data because it is the most effective instrument for field survey data collection. Likert scale of 1-5 that range from "Strongly Disagree" to "Strongly Agree" was used as parameters identifying respondent's opinions in the questionnaire. Information collected was on innovation capabilities, entrepreneurial attitude, and performance of SMEs. In terms of data analysis, data obtained from the survey was subjected to critical analysis and examinations that help the study make appropriate recommendations. The Statistical Package for Social Sciences (SPSS) software was used to run multiple linear regression to determine the relationship among the variables used. Variables used to measure innovative performance are product innovation, process innovation, organisational innovation and marketing innovation. With respect to performance, both financial and marketing parameters were used.

\subsection{Reliability of study}

The reliability of the various scales and the variables used were assessed using Cronbach alpha coefficient to check internal consistencies among the variables. Thus, the degree to which the items that make up the scale "hang together" and showing the extent to which the variables are measuring the underlying construct. Ideally, the Cronbach alpha coefficient of a scale should be above 0.7 (Creswell \& Clark, 2007). Table 1 show the reliability test conducted using Cronbach alpha. 
Table 1 Reliability of study

\begin{tabular}{lcc} 
Variable & Cronbach alpha coefficient & Number of items \\
\hline Product Innovation & 0.811 & 7 \\
Process Innovation & 0.824 & 7 \\
Organisational innovation & 0.737 & 5 \\
Marketing Innovation & 0.715 & 7 \\
Entrepreneurial Attitude & 0.721 & 10 \\
Performance & 0.709 & 8
\end{tabular}

Source: Researchers field work (2019)

The reliability of the study is based on various scales and variables used to evaluate internal consistency among the variables used. The Cronbach alpha coefficient is to make sure there is internal consistency among the variables used. Cronbach alpha coefficients of 0.7 is described as reliable whilst an alpha coefficient of 0.8 is preferable (Creswell 2009). The alpha coefficients of above 0.7 was achieved for all the variables (product innovation, process innovation, organisational innovation, marketing innovation, entrepreneurial attitude and performance).

\subsection{Correlation Matrix}

The Correlation matrix shows the relationship that existed between the variables used in the study. Correlation is used to assess if there is a multicollinearity between the variables used. For the study to be strong, the Correlation should not be more than 0.7 (Hair Jnr. 2007). As shown in the Correlation matrix (table 2), at the significant level of $99 \%$ (error margin of $0.1 \%$ ), there were no multicollinearity among the variables used for the study.

Table 2: Correlation matrix

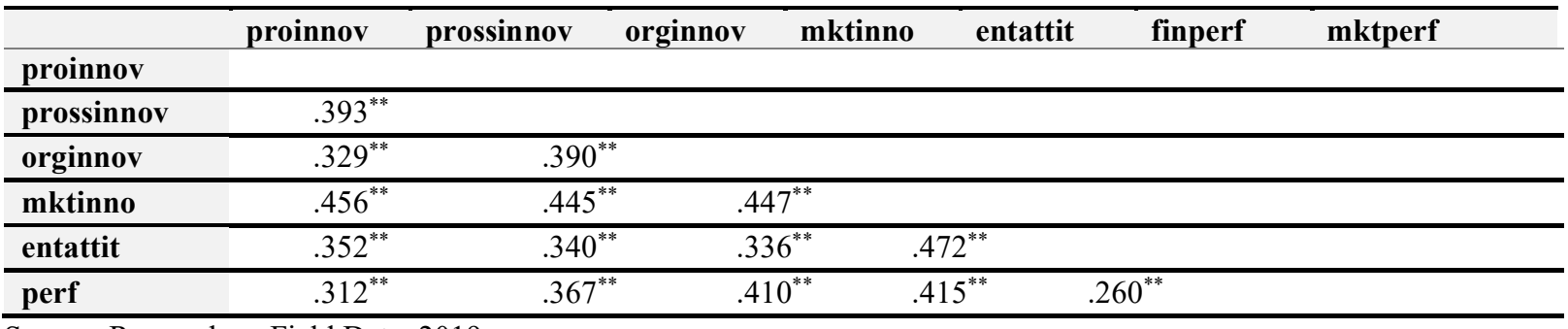

Source: Researchers Field Data, 2019

**. Correlation is significant at the 0.01 level (2-tailed).

Source: Researchers field work (2019)

Key: Proinnov $=$ product innovation, Prossinnov $=$ process innovation, orginnov $=$ organisational innovation, mktinno $=$ market innovation, entattit $=$ entrepreneurial attitude, perf $=$ performance,

\section{Findings and discussions}

\subsection{Demographic Information}

A comprehension of the respondent's profile is achieved by their demographic data. In this study, the demographics includes the gender, the age of respondents, position held by of the respondent. However, aside the demographics of the respondents, some basic company characteristics were sort. These characteristics includes company legal structure, SME type and the number of employees in the company and number of years of operation.

A summary of results of the demographic information and company characteristics from the analysed data are presented in tables 3 below. 


\begin{tabular}{|c|c|c|c|}
\hline \multicolumn{2}{|c|}{ VARIABLE } & FREQUENCY & PERCENTAGE \\
\hline GENDER & $\begin{array}{l}\text { Male } \\
\text { Female }\end{array}$ & $\begin{array}{l}208 \\
187\end{array}$ & $\begin{array}{l}52.7 \\
47.3\end{array}$ \\
\hline AGE & $\begin{array}{l}\text { Under } 30 \text { years } \\
30 \text { - } 40 \text { years } \\
41 \text { - } 50 \text { years } \\
\text { Above } 50 \text { years }\end{array}$ & $\begin{array}{c}33 \\
173 \\
140 \\
49\end{array}$ & $\begin{array}{c}8.4 \\
43.8 \\
35.4 \\
12.4\end{array}$ \\
\hline EMPLOYMENT STATUS & $\begin{array}{l}\text { Manager } \\
\text { Director } \\
\text { Others }\end{array}$ & $\begin{array}{c}223 \\
149 \\
23\end{array}$ & $\begin{array}{c}56.5 \\
37.7 \\
5.8\end{array}$ \\
\hline
\end{tabular}

Source: Researchers field work (2019)

The breakdown of the respondents by gender, age and employee status is shown in table 3 above. The demographic information indicates that out of the total number of 395 respondents, male respondents were 208 representing $52.7 \%$ as against 187 (47.3\%) female respondents. A summary of the age distribution of respondents results shows, out of the total sample population of the research, $33(8.4 \%)$ respondents were people below the ages of 30 years whilst 173 respondents representing $43.8 \%$ fell within the age bracket of 30 and 40 years. $140(35.4 \%)$ respondents were between the ages 41 and 50 years of age. However only 49 respondents representing $12.4 \%$ out of the total sample of 395 were above the age of 50. The above outputs in table 3 indicates that 149 respondents representing $37.3 \%$ were the entrepreneurs or owners of business who manage their firms as directors. Meanwhile, $223(56.5 \%)$ of the respondents were managers whilst $23(5.8 \%)$ respondents were performing other roles such as supervisors, departmental heads, marketers, administrators etcetera. The demographic information infers that SMEs in the Kumasi metropolis have more male entrepreneurs or SMEs managers than female and this population is dominated by young adult and adults within the ages of 30 and 50 years. Moreover, the analysis concludes that, most of SMEs in Kumasi are managed by the owners themselves. The demographic information implies that the SME subsector in the Ashanti Region is dominated by male. The age distribution points to the fact that more young adults and adults are involve in the SME subsector than the youth and the aged. However, almost all the SME firms are managed by the entrepreneurs themselves.

\subsection{SMEs Characteristics}

Table 4: SMEs Characteristics

\begin{tabular}{l|lcc}
\hline VARIABLE & & FREQ & PERCENTAGE \\
\hline \multirow{3}{*}{ YEARS OF OPERATION } & $0-5$ years & 84 & 21.3 \\
& $6-10$ years & 139 & 35.2 \\
NUMBER OF EMPLOYEES & $11-20$ years & 123 & 31.1 \\
& 20 years and above & 49 & 12.4 \\
& $0-5$ & & 40.3 \\
SME SUBSECTOR & $6-10$ & 159 & 31.4 \\
& $11-20$ & 124 & 22.8 \\
& 21 and above & 90 & 5.6 \\
& & 22 & 51.6 \\
& Trading & 204 & 14.9 \\
& Clothing and tailoring & 59 & 6.8 \\
& bakery & 27 & 8.9 \\
& food and beverages & 35 & 6.1 \\
& wood furniture & 24 & 4.3 \\
& soap and detergents & 17 & 7.3
\end{tabular}

Source: Researchers field work (2019)

The data captured in table 4 - in the years of operation column- indicates the operational history firms who were involved in the survey. The summery reveals that $21.3 \%$ of the respondent firms had existed for 5 years or below. $139(35.2 \%)$ firms had operated for 6 to 10 years. 123 businesses representing $31.1 \%$ that were involved in the survey had been in existence for a minimum of 11 and maximum of 20 years. Meanwhile 49 (12.4\%) firms recorded more than 20 years of existence. After the survey, it was revealed that, 159 SME firms representing 
40.3\% had employees between 0 and 5, 124 firms representing 31.4\% had $6-10$ employees. An employee population between 11 and 20, and 21 and above were reordered in $90(22.8 \%)$ and $22(5.6 \%)$ firms respectively. The results of this study showed that 204 firms representing 51.6\% were into trading, 59 firms (14.9\%) were companies that were involved in clothing and tailoring, 35 firms representing $8.9 \%$ were into food and beverages. $24(6.1 \%)$ and $17(4.3 \%)$ were into wood furniture and, soap and detergents business respectively. Moreover, 27 (6.8\%) firms were into bakery whilst 29 (7.3\%) firms representing 3.4\% were into other subsectors. The result of the research study on company characteristics implies, the SME subsector in the Ashanti region is dominated by trading with majority of them operating a sole trader business structure. Majority of these sole traders has an employee strength between one to ten employees meaning the SME is a one of the highest contributor to employment in Ghana. Considering the trading history behind the Kumasi metropolis, the fewer number of business that had an operating history of 20 years and above means that majority of SME firms cannot survive beyond thirty years. The study also discovered that $35.4 \%$ of the SMEs were officially registered and this implies that most of the SMEs in the Ashanti Region are formalising their operations.

\subsection{Effect of innovative capabilities on performance of SMEs.}

The output represents multiple linear regression which establish the relationship between innovative capabilities and performance of SMEs. The regressions equation was therefore $y=a+b_{1} X_{1}+b_{2} X_{2}+b_{3} X_{3}+b_{4} X_{4}$. In the computing the equation, it becomes; $\mathrm{y}=1.721+.088\left(\mathrm{X}_{1}\right)+.133\left(\mathrm{X}_{2}\right)+.221\left(\mathrm{X}_{3}\right)+.150\left(\mathrm{X}_{4}\right)+\mathrm{e}$. Product innovation (proinnov), process innovation (prossinnov), organisational innovation (orginnov) and marketing innovation (mktinno) were variables (independent variables) measuring innovative capabilities while performance (marketing and financial) was used as dependent variable.

The result shows a moderate relationship (R-value of 0.539 ) between innovative capabilities and performance of SMEs. The R square value of 0.291 shows that, $29.1 \%$ of SMEs performance can be explained by innovative capabilities. This point to the fact that there is a moderate relationship connecting innovative capabilities and SME firm's performance in Ghana. From the (Analysis of Variance) ANOVA results, the output depicts that the impact of innovative capabilities on the performance of SMEs is statistically significant and fit for the model. The output values of $(\mathrm{F}=39.918$; sig. $=0.000)$ confirms the statistical significance and fitness of the model. This confirms Calantone et al. (2002) study that posit that innovativeness is the most important determinant of an organization's performance. Guijaro, (2009) concluded, innovative activities are a necessity considering the scarce resources of SMEs. Table 5 shows the output of the result on model summary, ANOVA and the coefficient table

Table 5. Model Summary, ANOVA and Coefficients ${ }^{a}$ from regression output

\begin{tabular}{|c|c|c|c|c|c|c|c|}
\hline \multirow[b]{2}{*}{ Model } & \multicolumn{2}{|c|}{$\begin{array}{l}\text { Unstandardized } \\
\text { Coefficients }\end{array}$} & \multirow{2}{*}{\begin{tabular}{|l} 
Standardized \\
Coefficients
\end{tabular}} & \multirow[b]{2}{*}{$\mathrm{t}$} & \multirow[b]{2}{*}{ Sig. } & \multicolumn{2}{|c|}{ Collinearity Statistics } \\
\hline & B & Std. Error & & & & Tolerance & VIF \\
\hline $1 \quad$ (Constant) & 1.723 & .200 & & 8.599 & .000 & & \\
\hline Proinnov & .088 & .045 & .098 & 1.971 & .049 & .738 & 1.354 \\
\hline Prossinnov & .133 & .042 & .158 & 3.147 & .002 & .724 & 1.382 \\
\hline orginnov & .221 & .042 & .259 & 5.234 & .000 & .747 & 1.339 \\
\hline mktinno & .150 & .040 & .196 & 3.716 & .000 & .652 & 1.533 \\
\hline $\mathrm{R}$ & $.539^{\mathrm{a}}$ & & & & & & \\
\hline $\mathrm{R}^{2}$ & .291 & & & & & & \\
\hline F Statistics & $39.918 * * *$ & & & & & & \\
\hline
\end{tabular}

Source: Researchers field work (2019)

a. Dependent Variable: performance

Key: Proinnov $=$ product innovation, Prossinnov $=$ process innovation, orginnov $=$ organisational innovation, mktinno $=$ marketing innovation . 
In the regression results, the coefficient value (B) of 0.088 depicts a positive relationship between product innovation and SME performance. This means that when all other variables (process innovation, organisational innovations, and marketing innovations) are held constant, continues product innovation would lead to an increase in SME firms' performance. Product innovation is statistically significant making unique influence on SME performance with ( $\mathrm{t}$ value of 1.971 and significant of 0.049 ). SMEs that adopt product innovative practices recorded a significant growth in terms of the annual turnover (Forkuoh et. al., 2016). With regards to process innovation, the results, the coefficient value (B) of 0.133 is depicting a positive relationship with SME performance. This means that when the other independent variables are kept constant, a firm's performance will increase when process innovations increase. Process innovation is statistically significant to SME performance implying that it has a unique prediction on performance $(\mathrm{t}=3.147$ and $\mathrm{sig}=0.002)$. This supports Olson et al. (1995) acknowledgement of process innovation as a measure of decreasing the production cost thereby improving on the financial performance of a firm. Organization innovation was assessed and the results points to a coefficient value (B) of 0.221 portraying a positive relationship with SME performance. Organization innovation is statistically highly significant to SME performance implying that it is has a major influence on performance with a $t$ value of 5.234 and significant of 0.000 . The conclusion of the output supports a study by Günay which posit that that an organisational innovation creates time and economic benefits by facilitating the cooperation of business functions (Günay, 2007). Market innovation's regression results shows to a coefficient value (B) of 0.150 . The output means, there is a positive relationship with SME performance. Market innovation is statistically significant to SME performance implying a great influence on performance ( $\mathrm{t}$-value of 3.716 and significant of 0.000 ). After a careful analysis of the individual effect of the independent variables (product innovation, process innovation, organization innovation and market innovation), to identify the value that makes the greatest contribution to the performance of an SME firm, the beta variable outputs of the independent variables 0.098, 0.158, 0.259 and 0.196 which represents product innovation, process innovation, organization innovation and market innovation respectively were used. From the analysed results of the study, organisational innovation had the highest contribution to the performance of SMEs. Thus, if SMEs could rebrand their organisational structure, performance will increase

\subsection{Effect of entrepreneurial attitude on performance of SMEs}

The output establishes the relationship between entrepreneurial attitude and performance of SMEs. The regressions equation was therefore $y=a+b_{1} X_{1}$. In the computing the equation, it becomes; $y=3.0+.286\left(X_{1}\right)+e$. The study also assessed the extent to which of the entrepreneurial attitude affect the performance of SMEs. The results show that there is a weak relationship (R-value of 0.275) between entrepreneurial attitudes and the performance of an SME firm. The R square value of 0.075 shows that only $7.5 \%$ of SME's performance can explain entrepreneurial attitude. The ANOVA (Analysis of Variance) results however, shows that the variables used in the assessment of entrepreneurial attitude's effect on performance was statistically significant and fit. A statistical value of $(\mathrm{F}=$ 32.009 ; sig. $=.000$ ) indicate a model fit. Table 6 shows the results from the regression analysis run.

Table 6 summary of Model Summary, ANOVA and Coefficients

\begin{tabular}{|c|c|c|c|c|c|c|}
\hline \multirow{2}{*}{\multicolumn{2}{|c|}{ Model }} & \multicolumn{2}{|c|}{ Unstandardized Coefficients } & \multirow{2}{*}{$\begin{array}{c}\begin{array}{c}\text { Standardized } \\
\text { Coefficients }\end{array} \\
\text { Beta }\end{array}$} & \multirow[b]{2}{*}{$\mathrm{t}$} & \multirow[b]{2}{*}{ Sig. } \\
\hline & & B & Std. Error & & & \\
\hline \multirow[t]{2}{*}{1} & (Constant) & 3.000 & .199 & & 15.078 & .000 \\
\hline & entattit & .286 & .051 & .275 & 5.658 & .000 \\
\hline & $\mathrm{R}$ & $.275^{\mathrm{a}}$ & & & & \\
\hline & $\mathrm{R}^{2}$ & .075 & & & & \\
\hline & F statistics & $32.009 * *$ & & & & \\
\hline
\end{tabular}

a. Dependent Variable: Perf

Key: Perf $=$ performance, entattit $=$ entrepreneurial attitude

The regression result points to a coefficient value (B) of 0.286 . The output data depicts a positive relationship between entrepreneurial attitude and performance of an SME firm. The results suggest that all things been equal, the performance of an SME firm will be high when the entrepreneur have a good attitude to towards the firm and vice versa. Entrepreneurial attitude is statistically significant to SME financial performance implying it is having a unique influence on the financial performance of SMEs (t-value of 5.658 and significant of .000). According to a study by Gronum and Forsman (2011) the expertise, abilities and skills that constitute the attitude of an individual 
have a sizable impact on the performance of his business and this confirms the findings of this study. This study also supports Mahmood \& Hanafi's (2013) conclusion that entrepreneurial orientation substantially relates to the employer performance. The attitude that most business owners show towards their business sometimes makes it difficult to make any meaningful gains in their operations. These behaviours are characterised with lateness to work, poor customer service, unnecessary spending (drawings), and sweet-hearting among others. These attitudes result in poor performance hence must be discouraged for enhanced performance in lines of business operations

\section{Conclusion}

The findings of the research therefore conclude that performance of SMEs can be attributed to the innovative capabilities of that firm. There is a positive correlation between innovative capabilities and performance of SMEs. That is to say that the performance of SMEs is positively and significantly affected by the innovative capabilities of the firm and that the more an SME firm innovate, the more likely they are to record an increase in their performance. One can also not ignore the attitude of the owner for that matter behviours existed towards the operations of the business. Positive, innovative, dynamic and deterministic attitude towards SMEs operations will yield positive results hence enhancing its competitiveness.

\subsection{Recommendations}

Based on the findings of the study, it is recommended that for SME firms to be successful, and increase their performance, firms should focus much attention on its operations in terms of product innovation, marketing innovation, organisational innovation as well as process innovation as they all contributed positively and significance to performance. Small and Medium Scale Enterprises (SMEs) who needs to adopt some innovative strategies should concentrate on adopting innovative ways of improving their product. It is imperative for SMEs to invest in innovative ways of product improvement. It is recommended that in order to make SMEs more vibrant, entrepreneurs should develop a great zeal of seriousness in their business and not leave it solely in the hands of others when it comes to the operations of their businesses. However, entrepreneurs should develop their innovative skills because their attitudes have a direct effect on the overall performance of their firm. Business owners should also upgrade their skills in terms of attending business development seminars and workshops so as to learn the new trend in firm's development. Business owners should also take advantage in the digital age to introduce some level of technology in their operations in order to minimise cost and theft.

\subsection{Policy implications}

It is recommended that, government policies formulated for Small and Medium Enterprises should focus on promoting innovation among SME firms. Government should make it a priority to develop favourable environments that will make it easy for entrepreneurial firms to easily innovate the products. Firms innovative policies should be strengthened. SMEs or entrepreneurial associations should formulate policies that guide entrepreneurs' interference with their firms since it has an effect on both the financial and marketing performance. SME policy makers should develop policies that will help improve innovations among SME firms. Consistent training should be organised for owner managers to improve their skills as this has not been the practice in Ghana.

\section{References}

AMA. (2005). Marketing Accountability Study: White Paper. Chicago: American Marketing Association.

Ambler,T. (2000). Marketing and the Bottom Line. London: Financial Times/Prentice Hall. Anderson, E. W., Claes http://dx.doi.org/10.1287/mksc.16.2.129

Abor, J. and Quartey, P. (2010), "Issues in SME development in Ghana and South Africa", International Research Journal of Finance and Economics, Vol. 39 No. 6, pp. 215-228.

Andrews Tettey (2014). Entrepreneurial motivation and firm performance of Small and Medium Scale enterprises in the New Juaben Municipality Baldwin, J. R., \&

Afande, O.F. (2013), "Effects of strategic management practices on performance of financial institutions in Kenya: a case of Kenya post office savings bank", The International Journal of Management Science and Business Administration, Vol. 1 No. 7, pp. 122-141.

Afande, O.F. (2013), "Effects of strategic management practices on performance of financial institutions in Kenya: a case of Kenya post office savings bank", The International Journal of Management Science and Business Administration, Vol. 1 No. 7, pp. 122-141.

Agyapong, F.O., Agyapong, A. and Poku, K. (2017), "Nexus between social capital and performance of micro and small firms in an emerging economy: the mediating role of innovation", Cogent Business and Management, Vol. 4 No. 1, p. 1309784.

Agyapong, A., Ellis, F. and Domeher, D. (2016), “Competitive strategy and performance of family businesses: moderating effect of managerial and innovative capabilities", Journal of Small Business and Entrepreneurship, Vol. 28 No. 6, pp. 449-477. 
Anjum, Z. (2014), Startup Capitals: Discovering the Global Hotspots of Innovation, Random House India,New Delhi.

Barney, J. B. (1991). Firm Resources and Sustained Competitive Advantage. Journal of Management 17(1), 99120. http://dx.doi.org/10.1016/0048-7333(95)00875-6

Berry, M. A., \& Taggart, J. (1994). Managing Technology and Innovation: A Review. R\&D Management, 24, 341-353. http://dx.doi.org/10.1111/j.1467-9310.1994.tb00889.x

Benedict Afful Jr (2010). Determinants of innovation among Micro, Small and Medium Scale Enterprises in the Ghanaian apparel industry

Bertrand, M., \& Mullainathan, S. (2001). Do People Mean What They Say? Implications for Subjective Survey Data. American Economic Review, 91(2), 67-72. http://dx.doi.org/10.1257/aer.91.2.67

Bilton, C. and Cummings, S. (2010), Creative Strategy: Reconnecting Business and Innovation (Vol. 3), John Wiley and Sons, New York, NY.

Basterretxea, I., \& Martinez, R. (2012). Impact of management and innovation capabilities on performance: Are cooperatives different. Annals of Public and Cooperative Economics, 83 (3), 357-381.

Bonoma, T. V, \& Clark, B. C. (1988). Marketing Performance Assessment. Boston: Harvard Business School Press.

Buzzell, R., \& Gale, B. (1987). The PIMS principles: Linking strategy to performance. Free Press.

Camp, R. C. (1989). Benchmarking: The Search for Best Practices That Lead to SuperiorPerformance. Milwaukee, WI: ASQC Quality Press.

Clark, B. H. (1999). Marketing performance measures: History and interrelationships. J. Mark. Manage, 15(8), 711-733. http://dx.doi.org/10.1362/026725799784772594

Czarnitzki, D., \& Spielkamp, A. (2003). Business services in Germany: Bridges for innovation. The Service Industries Journal, 23(2), 1-30. http://dx.doi.org/10.1080/02642060412331300862

Camps, S. and Marques, P. (2014), "Exploring how social Capital facilitates innovation: the role of innovation enablers", Technological Forecasting and Social Change, Vol. 88, pp. 325-348.

Chrysostome, E.V. and Molz, R. (Eds) (2014), Building Businesses in Emerging and Developing Countries: Challenges and Opportunities (Vol. 111), Routledge, New York, NY.

Cofie, A.A. (2012), "The challenges of financing small and medium scale enterprises (SMEs) in the Ashanti region-a case study of stanbic bank (gh) ltd", Doctoral dissertation.

Collis, J. and Hussey, R. (2013), Business Research: A Practical Guide for Undergraduate and Postgraduate Students, Palgrave macmillan, Basingstoke.

Dauda, Y.A., Akingbade, W.A. and Akinlabi, H.B. (2010), "Strategic management practice and corporate performance of selected small business enterprises in Lagos metropolis", International Journal of Business and Management, Vol. 5 No. 11, p. 97.

D'Este, P. (2002). The distinctive patterns of capabilities accumulation and inter-firm heterogeneity: the case of the Spanish pharmaceutical industry. Industrial and Corporate Change, 11(4), 847-874. http://dx.doi.org/10.1080/02642060412331300862

Damanpour, F., \& Evan, W. M. (1984). Organisational innovation and performance: the problem of “organisational lag". Administrative Science Quarterly, 29(3), 392409.http://dx.doi.org/10.2307/2393031

Daneels, E. (2002). The dynamics of product innovation and firm competences. StrategicManagement Journal, 23, 1095-1121. http://dx.doi.org/10.1002/smj.275

Davis, C. R. (2002). Calculated Risk: A Framework for Evaluating Product Development.Sloan Management Review, 43(4), 71-77.

Dougherty, D. (1992). Interpretative barriers to successful product innovation in large firms.Organization Science, 3, 179-202. http://dx.doi.org/10.1287/orsc.3.2.179

Drucker, P. F. (1985). Innovation and Entrepreneurship. Butterworth-Heinemann, Oxford.

Fagerberg, J., Mowery, D. C., \& Nelson, R. R. (2004). The Oxford Handbook of Innovation. Oxford University Press.

Firms and Functional Areas for Strategic Benchmarking. The Engineering Economist, 46(4),274-99. http://dx.doi.org/10.1080/00137910108967578

Freeman, C., \& Soete, L. (1997). The Economics of Industrial Innovation (3rd ed.). London:Pinter.

Ghana Statistical Service (2006). 2003 national industrial census. Retrieved from http:// www.gssghana.org.

Ghana Investment Promotion Centre (2008). Ghana investment profile. Retrieved from http://www.gipc.org.gh. Brownlie, D. (2000). Benchmarking Your Marketing Process. Long Range Planning, 32(1), 88-95. http://dx.doi.org/10.1016/S0024-6301(98)00129-0

Geroski, P. (1995). Innovation and competitive advantage. Working Paper No. 159, OECD, Paris.

Guan, J. (2002). Comparison Study of Industrial Innovation between China and Some European Countries. Production and Inventory Management Journal, 43(3). 
Guan, J., \& Ma, N. (2003). Innovative capability and export performance of Chinese firms. Technovation, 23, 737-747. http://dx.doi.org/10.1016/S0166-4972(02)00013-5

Hagedoorn, J., \& Cloodt, M. (2003). Measuring innovative performance: is there an advantage in using multiple indicators? Research Policy, 32, 1365-1379. http://dx.doi.org/10.1016/S0048-7333(02)00137-3

Han, J. K., Kim, N., \& Srivastava, R. K. (1998). Market orientation and organisational performance: is innovation the missing link? Journal of Marketing, 62(4), 30-45.http://dx.doi.org/10.2307/1252285

Hafeez, MH, Shariff, MN, Lazim.M, 2012, Relationship between Entrepreneurial Orientation, Firm Resources, SME Branding and Firm's Performance: Is Innovation the Missing Link?, American Journal of Industrial and Business Management, 2012, 2, 153-159 , (online) pp: 153-159 (www.scirp.org /.../ PaperInformation.aspx? ... -accessed 14 Nov 2012)

Henderson, R., \& Cockburn, I. (1994). Measuring competence: Exploring firm effects in pharmaceutical research. Strategic Management Journal, 15(special issue), 63-84. http://dx.doi.org/10.1002/smj.4250150906

Hooley, G. J., Greenley, G., Cadogan, J. W., \& Fahy, J. (2005). The performance impact of marketing resources. Journal of Business Research, 58(1), 18-27.http://dx.doi.org/10.1016/S0148-2963(03)00109-7

Hooley, G., \& Greenley, G. (2005). The resource underpinnings of competitive positions.Journal of Strategic Marketing, 13(2), 93-116.http://dx.doi.org/10.1080/09652540500082968

Jen Lin, R., Huei Chen, R., \& Shun Chiu, K. (2010). Customer relationship management and innovation capability: an empirical study. Industrial Management \& Data Systems, 111-133. http://dx.doi.org/10.1108/02635571011008434

Johne, A., \& Davies, R. (2000). Innovation in medium-sized insurance companies: how marketing adds value. International Journal of Bank Marketing, 18(1), 6-14. http://dx.doi.org/10.1108/02652320010315316

Kirpalani, V. H., \& Stanley, S. S. (1973). Financial Dimensions of Marketing Management.

Kitapci, H., Aydin, B., \& Celik, V. (2011). The effects of organizational learning capacity and innovativeness on financial performance: An empirical Study. African Journal of Business Management, 6(6), 2332-2341.

Kotler, P. (1991). Marketing Management: Analysis, Planning, Implementation, \& Control (7th ed.). Prentice Hall, Englewood Cliffs, New York.

Luo, C. A., Chang, H., \& Su, C. (2012). 'Balanced scorecard' as an operation-level strategic planning tool for service innovation. The Service Industries Journal, 32(12), 1937-1956.

Michael Senanu Affram (2011). Innovation among small and medium enterprises (SMEs) in the volta region: The role of tacit knowledge.

Moore, D. P., \& Buttner, E.H. (1997). Women entrepreneurs: Moving beyond the Glass Ceiling. Newbury Park: Sage Publications

OECD. (2005). Oslo Manual: Proposed Guidelines for Collecting and Interpreting Technological Innovation Data. Paris.

OECD. (2007). Summary report of the study of globalisation and innovation in the business services sector. Paris.

Oke, A. (2007). Innovation types and innovation management practices in service companies. International Journal of Operations and Production Management, 27(6), 564587.http://dx.doi.org/10.1108/01443570710750268

Rahman, N. A., Yaacob, Z., \& Radzi, R. M. (2016). An overview of technological innovation on SMEs survival: a conceptual paper. Procedia - Social and Behavioral Sciences, 224, 508-515. https://doi.org/10.1016/j.sbspro.2016.05.427

Seidu Awudu (2012). A study of the marketing activities of Small and Medium Enterprises in the Tema metropolis

Stanislawski, R., \& Lisowska, R. (2015). The relations between innovation openness (open innovation) and the innovation potential of SMEs. Procedia - Economics and Finance, 23, 1521-1526. https://doi.org/10.1016/S2212-5671(15)00330-5

U1 Hassan, M., Shaukat, S., Saqib, M., Naz, S. (2013), Effects of innovation types on firm performance: An empirical study on Pakistan's manufacturing sector. Pakistan Journal of Commerce and Social Sciences, 7 (2), 243-262.

UNCTAD (2003). African technology gap. Geneva: United Nations.

UNCTAD, (2005). E-Commerce and development report 2004. Geneva: Author Wang, C. (2008). Evaluating firm technological innovation capability under uncertainty.

Weerawardena, J. (2003). Exploring the role of market learning capability in competitive strategy. European Journal of Marketing, 37(3/4), 407-30.http://dx.doi.org/10.1108/03090560310459023

Wei, H., \& Wang, E. (2005). Importance of market orientation, learning orientation, and quality orientation capabilities in TQM: An example from Taiwanese software industry. 
William, C. H., \& Michael, E. B. (1995). The impact of sales and income growth on profitability and market value measures in actual and simulated industries..

Wood, P. (2005). A service-informed approach to regional innovation - or adaptation? The Service Industries Journal, 25(4), 429-445. http://dx.doi.org/10.1080/0264206050009206 